\title{
$\mathrm{AHP}$ 를 이용한 서울특별시소방학교 교육훈련프로그램 분석 김 진 근** 박 찬 석** \\ *서울특별시소방학교 소방과학연구센터 - ${ }^{* *}$ 우송정보대학교 소방안전관리과
}

\section{An Analysis for the Educational Training Program of Seoul Fire Academy through AHP}

\author{
Jin Keun Kim ${ }^{*} \cdot$ Chan Seok Park ${ }^{* *}$
}

*Fire Science Research Center, Seoul Metropolitan Government Fire Academy

${ }^{* *}$ Dept. of Fire Safety Management, Woosong College

\begin{abstract}
In recent years, the surroundings of Fire have rapidly changed and citizens need for Fire have been demanding very high. Under these situations, in order for satisfaction to all these demands, Seoul Metropolitan Government Fire Academy(SFA) have only to improve its educational training program as the fire educational training center in Korea. The purpose of this study is to scrutinize current educational training program of SFA and measure the relative weight among the hierarchy of disaster management(prevention and mitigation-preparedness-response-recovery) by using the Analytic Hierarchy Process(AHP). The result of this study presents that how many hours must be allocated and set the educational training program with scientific and systematic way of AHP compared the current program of SFA in 2013. And This study is applied to increase access and comprehension about the AHP and will be able to present guideline for the selection of optimal the educational training of SFA to serve Seoul citizens the best Fire services.

Keywords : AHP(Analytic Hierarch Process), Hierarch of Disaster Management, Prevention and Mitigation, Preparedness, Response, Recovery

\section{1. 서 론}

\section{1 연구 필요성 및 목적}

서울특별시 화재피해(인적피해 및 재산피해)의 심화 와 구조출동 및 요구조자 구조, 구급 출동 및 이송인원 은 매년 꾸준히 증가추세에 있다. 이는 안전에 대한 인 식이 납세의무자의 권리의식과 스스로 안전을 담보할

수 없는 복합적이고 다 기능적인 사회환경에 기인한 것으로 앞으로도 포괄적인 소방안전수요 요구와 일상 생활안전까지 침투를 요구하는 소방행정수요는 더욱더 심화되고 있다. 그러나 2013년 서울특별시 소방공무원 1 인당 서울시민의 수는 1,605 명으로 전국 소방공무원 1 인당 평균 국민 1,301 명에 비하여 부족한 상태이고 경 찰조직과 비교해도 4 배(경찰 1 인당 주민 수 : 442 명) 정 도의 인력이 부족한 상태이다*. 따라서 소방조직의 정 예화 및 첨단화와 소방서비스의 고품질화가 절실하다.
\end{abstract}

† Corresponding Author: Chan-Seok Park,

Dept. of Fire Safety Management, Woosong College,

M • P: 010-2228-7604, E-mail: ppcwh@snu.ac.kr

Received April 20, 2014; Revision Received June 20, 2014; Accepted September 20, 2014.

* 서울특별시 소방재난본부 내부통계자료(2013. 6.30. 기준)(01) 
본 연구에서는 서울특별시라는 초거대도시의 재난취 약성을 잘 반영할 수 있도록 $\mathrm{AHP}$ (계층분석)을 이용하 여 소방공무원이 현업에서 직무역량을 강화시킬 수 있 는 재난관리 우선순위를 반영한 과학적이고 체계적인 교육훈련 프로그램을 설계하는 것이 본 연구의 목적이 라 할 수 있다.

\section{2 연구 방법}

서울특별시소방학교 교육훈련 프로그램을 재난관리 4단계(예방-대비-대응-복구)와 접목시켜 교육훈련 프 로그램을 체계적으로 재분류하였다. 그리고 서울특별시 소방재난본부 산하 광진소방서, 강남소방서, 구로소방 서 소속 소방공무원을 대상으로 행정, 화재진압, 구조, 구급 각각의 전체인원 크기에 비례하도록 표본을 추출 하는 비례층화표본추출(proportional stratied sampling) 방법을 사용하여 285명의 표본(sample)으로 Likert가 개발한 5 점 척도의 형식으로 구성된 설문지를 통해 설 문조사방법을 실시하였다. 그리고 조사자료를 토대로 SPSS(PASW) 20.0 통계 프로그램을 이용하여 서울특 별시소방학교 교육훈련이 조직효과성에 미치는 영향과 서울특별시소방학교에서 직무중심 교육훈련을 받지 않 은 집단과 받은 집단 간 평균비교를 위해 독립표본 T-test를 통하여 실증검증을 하였다. 마지막으로 현재 서울특별시소방학교 교육훈련 프로그램을 재난관리 4 단계(예방-대비-대응-복구)와 $\mathrm{AHP}$ (계층분석) 기법을 접목하여 재난관리 중요도를 반영한 재난에 강한 교육 훈련 프로그램 모델의 방향을 제시하였다.

\section{2. 실증연구의 설계 및 가설의 설정}

\section{1 실증연구의 설계}

서울특별시소방학교 직무중심 교육훈련에 관한 실증 검증을 위해 서울특별시소방학교 직무중심 교육훈련이 조직효과성에 유의한 영향을 주는지 검증하기 위한 회 귀분석을 실시하기로 한다[1].

$<$ Table $1>$ Fire educational training and organizational effectiveness

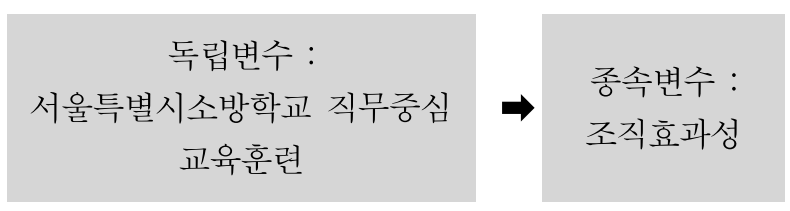

그리고 서울특별시소방학교 직무중심 교육훈련을 받은 집 단과 그렇지 않은 집단이 조직효과성(종속변수)에 미치는 영향에 차이가 있는가를 알아보기 위하여 '두 집단 간의 평균차이'를 분석하기 위해 T-test를 실시하기로 한다.

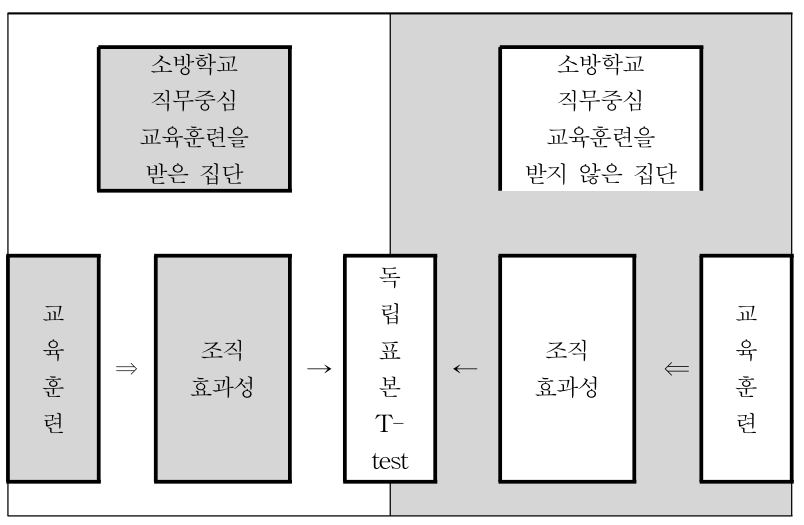

[Figure 1] Model of two group for Analysis

\section{2 가설의 설정}

서울특별시소방학교 직무중심 교육훈련과 조직효과 성 간의 선형관계를 알기 연구가설은 다음과 같다.

가설 I : 서울특별시소방학교 직무중심 교육훈련은 조직효과성에 유의한 영향을 미칠 것이다.

서울특별시소방학교 직무중심 교육훈련을 받은 집단 과 그렇지 않은 집단 간의 조직효과성 차이를 비교하 기 위한 연구가설은 다음과 같다.

가설ㅍ : 서울특별시소방학교 직무중심 집합교육훈련을 받은 집단이 그렇지 않은 집단보다 조직효과성이 높다.

$<$ Table 2> Reliability verification

\begin{tabular}{|c|c|c|c|c|c|}
\hline \multirow{2}{*}{\multicolumn{2}{|c|}{ 종 속 변 수 }} & \multirow{2}{*}{\multicolumn{2}{|c|}{ 문항 수 }} & \multicolumn{2}{|c|}{ 신뢰도 계수(Cronbach's Alpha) } \\
\hline & & & & \multirow{2}{*}{$\begin{array}{c}\begin{array}{c}\text { 항목이 삭제된 후 } \\
\text { Cronbach's Alpha }\end{array} \\
0.835\end{array}$} & $\begin{array}{l}12 \text { 개 문항에 대한 } \\
\text { Cronbach's Alpha }\end{array}$ \\
\hline \multirow{12}{*}{$\begin{array}{l}\text { 조 직 } \\
\text { 효과성 }\end{array}$} & \multirow{8}{*}{$\begin{array}{c}\text { 조직몰 } \\
\text { 입 }\end{array}$} & \multirow{8}{*}{$\begin{array}{c}8 \\
\text { 문항 }\end{array}$} & 문항 1 & & \multirow{12}{*}{0.848} \\
\hline & & & 문항 2 & 0.848 & \\
\hline & & & 문항 3 & 0.837 & \\
\hline & & & 문항 4 & 0.822 & \\
\hline & & & 문항 5 & 0.833 & \\
\hline & & & 문항 6 & 0.833 & \\
\hline & & & 문항 7 & 0.870 & \\
\hline & & & 문항 8 & 0.827 & \\
\hline & \multirow{4}{*}{$\begin{array}{l}\text { 직무만 } \\
\text { 족 }\end{array}$} & \multirow{4}{*}{$\begin{array}{c}4 \\
\text { 문항 }\end{array}$} & 문항 1 & 0.841 & \\
\hline & & & 문항 2 & 0.831 & \\
\hline & & & 문항 3 & 0.832 & \\
\hline & & & 문항 4 & 0.828 & \\
\hline
\end{tabular}




\section{3. 검증결과 및 해석}

\section{1 측정도구의 신뢰도와 타당도 검증}

\subsection{1 신뢰도 검증}

조직효과성의 지표는 조직몰입 8문항과 직무만족 4 문항에 대해서 해당 문항을 제거한 신뢰도 계수 (Cronbach's Alpha)가 전체 신뢰도 계수보다 높은 특 이한 값인 '조직몰입 7 '문항을 제거할 필요가 있다 (Table2 참조). 따라서 '조직몰입 7'문항을 제거한 신뢰 도 계수(Cronbach's Alpha)는 아래<Table 3>와 같다.

$<$ Table $3>$ Final results of reliability verification

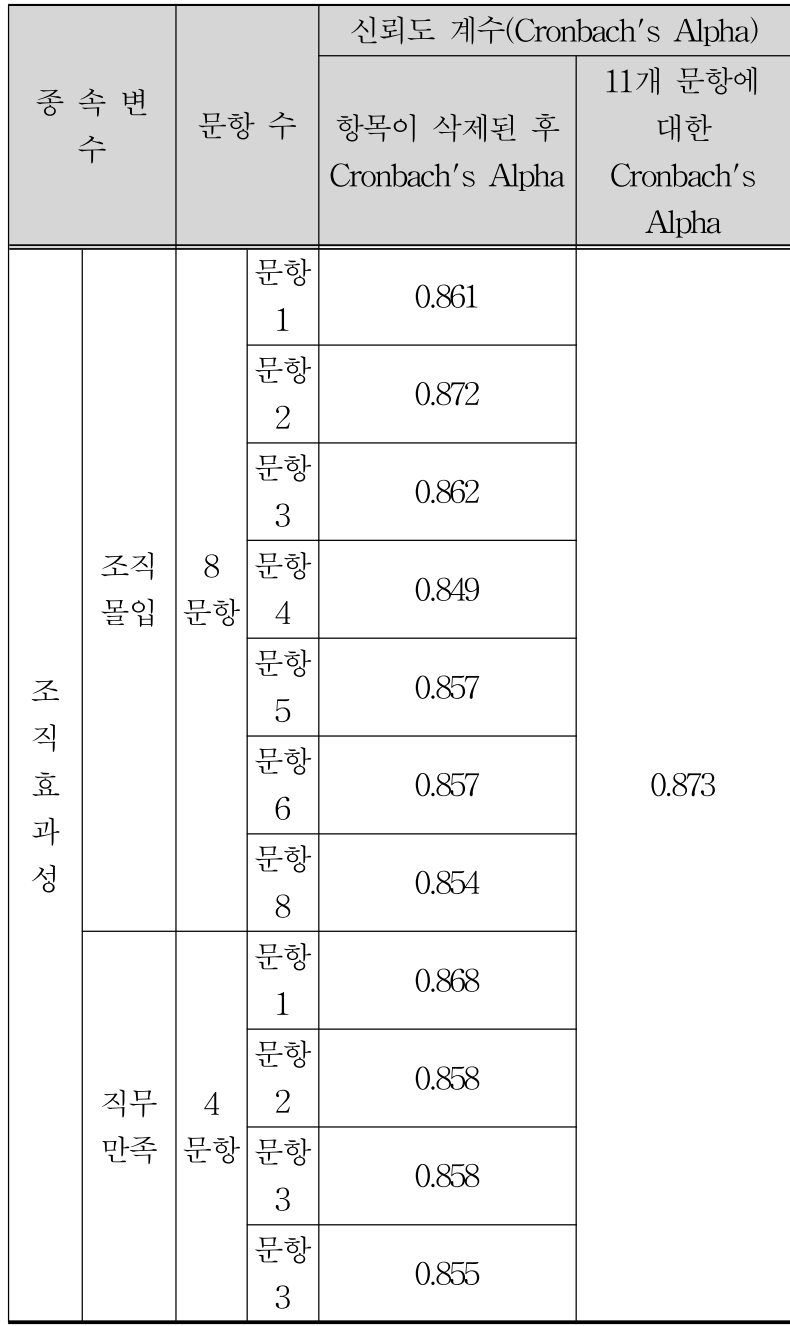

\subsection{2 타당도 검증}

조직효과성의 측정지표로 널리 사용되어지고 있는 조직몰입과 직무만족을 가지고 소방조직에서도 마찬가 지로 타당도가 높은 지표가 되는지 분석하였다 [2]. 조직효과성의 구성요소인 조직몰입과 직무만족은 국·내
외로 이미 개발되어 활용되어온 지표로 이를 소방조직 에 적용한 결과 직무만족과 조직몰입으로 2 개의 요인 으로 나타나는 결과를 얻을 수 있었다(Table 4 참조).

$<$ Table $4>$ results of factor analysis

\begin{tabular}{|c|c|c|c|}
\hline \multirow{2}{*}{ 문항 } & \multicolumn{2}{|c|}{ 성분(요인적재값) } & 공통값(추 \\
\cline { 2 - 4 } & 요인 1 & 요인 2 \\
\hline \hline 조직몰입 1 & .261 & .633 & .468 \\
조직몰입 2 & -.084 & .753 & .574 \\
\hline 조직몰입 3 & .430 & .443 & .381 \\
\hline 조직몰입 4 & .570 & .563 & .641 \\
조직몰입 5 & .165 & .800 & .667 \\
조직몰입 6 & .302 & .671 & .542 \\
조직몰입 8 & .450 & .579 & .538 \\
직무만족 1 & .727 & .054 & .532 \\
직무만족 2 & .869 & .108 & .767 \\
직무만족 3 & .600 & .374 & .499 \\
직무만족 4 & .804 & .235 & .702 \\
\hline 고유값(eigen & 4.910 & 1.401 & \\
value) & & & \\
설명분산(\%) & 44.638 & 12.736 & \\
누적분산(\%) & 29.054 & 57.373 & \\
\hline
\end{tabular}

<Table 4>는 조직몰입 문항 7번을 제외한 조직효과 성의 직무만족과 조직몰입이라는 2 개의 요인을 분석한 결과로써 조직효과성 종속변수 전체 설명력이 $57.373 \%$ 로 나타났다. 그리고 요인적재량(값)과 공통값이 0.4 미 만인 설문항목인 '조직몰입 3' 문항을 제외하였다.

결국 신뢰도 및 타당도 분석을 통해서 설문문항 중 ‘조직몰입 3' 문항(타당도 문제문항)과 ‘조직몰입 7' 문 항(신뢰도 문제 문항)을 제외한 나머지 문항을 가지고 가설을 검증하게 되었다.

\section{2 가설검증의 결과 및 해석}

\subsection{1 표본의 인구통계학적 특성}

서울특별시 소방재난본부 산하 3개소방서(광진·강남. 구로소방서)와 해당 소방서의 19 개 안전센터(광진소방 서 소속 7 개, 강남소방서 소속 5 개, 구로소방서 소속 7 개 안전센터) 및 3 개 구조대(각각 소방서 소속 구조대) 의 내근 및 외근 현장활동 소방공무원으로부터 설문지 를 받아 모두 285개의 설문지를 회수하여 분석하였다. 
$<$ Table 5> General statistics of samples*

\begin{tabular}{|c|c|c|c|}
\hline 기 & 위 & 빈도(표본수-명) & 백분율(\%) \\
\hline \multirow{2}{*}{ 성 별 } & 남 & 266 & 93.3 \\
\hline & 여 & 19 & 6.7 \\
\hline \multirow{5}{*}{ 계 } & 소방사 & 82 & 28.8 \\
\hline & 소방교 & 47 & 16.5 \\
\hline & 소방장 & 115 & 40.4 \\
\hline & 소방위 & 32 & 11.2 \\
\hline & 소방경 & 9 & 3.2 \\
\hline \multirow{4}{*}{ 연 령 } & 30세미만 & 26 & 9.1 \\
\hline & 30-39 & 115 & 40.4 \\
\hline & $40-49$ & 103 & 36.1 \\
\hline & $50-59$ & 41 & 14.4 \\
\hline \multirow{5}{*}{$\begin{array}{r}\text { 소방공무욱 } \\
\text { 재직기간 }\end{array}$} & 5년미만 & 80 & 28.1 \\
\hline & 5-10년미만 & 44 & 15.4 \\
\hline & 10-15년미만 & 46 & 16.1 \\
\hline & 15-20년미만 & 46 & 16.1 \\
\hline & 20년이상 & 69 & 24.2 \\
\hline \multirow{4}{*}{ 근무형 다 } & 화재진압관련업무 & 152 & 53.3 \\
\hline & 구조업무 & 38 & 13.3 \\
\hline & 구급업무 & 45 & 15.8 \\
\hline & 행정업무 & 50 & 17.5 \\
\hline
\end{tabular}

$<$ Table 6> Analysis of regression

\begin{tabular}{|c|c|c|c|c|c|c|c|}
\hline 독립변수 & 종속변수 & $\mathrm{N}$ & 표준오차 & $\beta$ & $\mathrm{t}$ 값 & 유의확률 & 통계량 \\
\hline \multirow[b]{2}{*}{ 교육훈련 } & 상수 & \multirow[b]{2}{*}{155} & .139 & - & 25.231 & .000 & \multirow{2}{*}{$\begin{array}{c}\text { 공차한계(TOL) } 1.000 \\
\text { 분산팽창요인(VIF)1.0 } \\
0\end{array}$} \\
\hline & 조직효과성 & & .038 & .047 & .794 & $.428 *$ & \\
\hline
\end{tabular}

$* \mathrm{p}<.05, * * \mathrm{p}<.01, * * * \mathrm{p}<.001$

표본의 인구통계학적 특성은 남성이 $93.3 \%$ 로 표본의 대부분을 차지하였으며, 연령대는 30세 이상 39세 미만 이 $40.4 \%$ 로 가장 많았고, 40 세 이상 50 세 미만이 뒤이 어 $36.1 \%, 50$ 세 이상 60 세 미만이 $14.4 \%, 30$ 세 미만이 $9.1 \%$ 순이었다. 담당업무는 화재진압과 관련된 업무(경 방, 기관 등)가 $53.3 \%$ 로 가장 많았다(<Table $5>$ 참조).

\subsection{2 회귀분석 결과(가설 I 의 검증)}

서울특별시소방학교 직무중심 교육훈련과 조직효과 성 간의 관계를 분석하기 위하여 조직효과성을 종속변 수로 설정하고, 직무중심 교육훈련을 독립변수로 설정 하여 회귀분석을 실시하였다.

회귀분석 결과를 보면 서울특별시소방학교 직무중심
집합교육훈련을 받은 집단(155명)은 조직효과성과 정 $(+)$ 의 관계에 있으나, 가설 I의 검정결과 $\mathrm{t}$ 값은 0.794( $\mathrm{p}=0.428$ )로 통계적으로 0.05 의 유의수준 하에서 가설 I 은 기각한다. 즉 서울특별시소방학교 직무중심 교육훈련은 조직효과성에 아무런 유의미한 영향을 미 치지 않음이 검증되었다(<Table 6> 참조).

구체적으로 서울특별시직무중심 교육훈련을 받은 집 단의 재난관리 단계별 교육내용을 살펴보면 직무중심 교육훈련을 받지 않은 사람은 130 명이고 받은 사람은 149 명이다. 그리고 6 명은 결측값으로 나타났다. 결측 값은 직무중심 교육훈련을 받았다고 하면서 재난관리 단계별 교육훈련을 체크하지 않은 표본이라고 할 수 있다(<Table $7>$ 참조)

* 기술통계량에서 전체 표본은 285명으로 해당 표에서는 결측값이 있는 표본은 제외(02). 
$<$ Table $7>$ Statistics of educated group and non-educated group

\begin{tabular}{|c|c|c|c|c|c|}
\hline & 유효/결측 & 빈도 & 퍼센트 & 유효퍼센트 & 누적퍼센트 \\
\hline \multirow{6}{*}{ 유 효 } & 받지 않은 집단 & 130 & 45.6 & 46.6 & 46.6 \\
\hline & 예방단계관련교육훈련 & 46 & 16.1 & 16.5 & 63.1 \\
\hline & 대비단계관련교육훈련 & 49 & 17.2 & 17.6 & 80.6 \\
\hline & 대응단계관련교육훈련 & 48 & 16.8 & 17.2 & 97.8 \\
\hline & 복구단계관련교육훈련 & 6 & 2.1 & 2.2 & 100.0 \\
\hline & 합계 & 279 & 97.9 & 100.0 & \\
\hline 결 측 & 결측 값 & 6 & 2.1 & & \\
\hline 합 계 & & 285 & 100.0 & & \\
\hline
\end{tabular}

\subsection{3 독립표본 $\mathrm{T}$ 검정 결과(가설 $\Pi$ 의 검정)}

서울특별시소방학교 직무중심 교육훈련 집단과 받지 않은 집단 간의 조직효과성(종속변수)에 미치는 영향에 차이가 있는가를 비교하기 위하여 두 집단 간의 독립 표본 T검정을 실시하였다.

$<$ Table 8> Levene's homogeneity of variance test

\begin{tabular}{|c|c|c|c|}
\hline \multirow{2}{*}{ 종속변수 } & \multirow{2}{*}{ 범 } & \multicolumn{2}{|c|}{ Levene의 등분산 검정 } \\
\hline & & F & 유의확률 \\
\hline \multirow{2}{*}{$\begin{array}{l}\text { 조직 } \\
\text { 효과성 }\end{array}$} & 등분산이 가정됨 & \multirow[b]{2}{*}{1.934} & \multirow[b]{2}{*}{$.165 *$} \\
\hline & $\begin{array}{c}\text { 등분산이 가정되지 } \\
\text { 않음 }\end{array}$ & & \\
\hline
\end{tabular}

$* \mathrm{p}<.05, * * \mathrm{p}<.01, * * * \mathrm{p}<.001$

실시 결과, Levene의 등분산 검정결과 조직효과성의 경우 $\mathrm{F}$ 값은 $1.934, \mathrm{~F}$ 값의 유의확률은 .165 인데 유의확 률의 기준인 0.05 보다 크므로 귀무가설을 채택하여 등 분산이 가정된다. 따라서 조직효과성의 경우는 등분산 을 가정하여 T검정을 수행하기로 한다.

$<$ Table 9> Result of T-test

\begin{tabular}{|c|c|c|c|c|c|c|c|}
\hline $\begin{array}{l}\text { 종속 } \\
\text { 변수 }\end{array}$ & 구분 & $\mathrm{N}$ & 평균 & $\begin{array}{c}\text { 표준편 } \\
\text { 차 }\end{array}$ & $\begin{array}{c}\text { 평균의 } \\
\text { 표준오 } \\
\text { 차 }\end{array}$ & $\mathrm{t}$ & $\begin{array}{c}\text { 유의확률 } \\
\text { (p) }\end{array}$ \\
\hline 조직 & $\begin{array}{c}\text { 교육훈련 } \\
\text { (유) }\end{array}$ & 151 & 3.6695 & .62290 & .05069 & \multirow{2}{*}{1.383} & \multirow{2}{*}{$.168 *$} \\
\hline 효과성 & $\begin{array}{c}\text { 교육훈련 } \\
\text { (무) }\end{array}$ & 132 & 3.5705 & .57582 & .05012 & & \\
\hline
\end{tabular}

$* \mathrm{p}<.05, * * \mathrm{p}<.01, * * * \mathrm{p}<.001$

독립표본 T검정 결과를 보면 조직효과성에 있어서는 서울소방학교 직무중심 집합교육훈련을 받은 집단의 평균은 3.6695로 그렇지 않은 집단의 평균인 3.5705 보 다 아주 근소하게 높으나, 이는 유의수준 0.05 에서 유
의한 차이를 보인다고 할 수 없다. 따라서 "서울특별시 소방학교 직무중심 교육훈련을 받은 집단이 그렇지 않 은 집단보다 조직효과성이 높다.”라는 가설 $\Pi$ 은 기각된 다. 따라서 서울소방학교 직무중심 집합교육훈련을 받 은 집단과 그렇지 않은 집단 간에는 $95 \%$ 의 신뢰수준 하에서 유의한 차이가 없다는 것이 검증되었다<Table 9> 참조).

\subsection{4 해 석}

서울특별시소방학교 직무중심 교육훈련이 소방조직 에 미치는 영향을 보다 정교하게 분석하기 위해서는 다수의 독립변수와 종속변수 간의 관계를 규명할 경로 분석을 하여 다수의 독립변수가 조직에 얼마만큼 영향 을 주는지에 관한 분석이 이루어져야 할 것이지만, 간 접적인 방법으로 서울특별시소방학교 직무중심 교육훈 련이 조직효과성에 미치는 영향을 분석하여 활용하고 자 했다.

분석결과 먼저 가설 I 과 관련하여 서울특별시소방학 교 직무중심 교육훈련은 종속변수인 조직효과성에 얼 마나 영향을 미치는지에 대하여 회귀분석결과 유의하 지 않아 가설 I을 기각하였다. 즉, 서울특별시소방학교 직무중심 교육훈련이 조직효과성에 긍정적인 영향을 미치지 못하는 것으로 해석할 수 있다.

그리고 가설 $\Pi$ 와 관련하여 서울특별시소방학교 직무 중심 교육훈련을 받은 집단은 그렇지 않은 집단 간의 조직효과성에 얼마만큼 영향을 주는가에 관한 비교에 있어서 이 또한 유의한 결과를 도출하지 못하였다. 즉, 서울특별시소방학교 직무중심 교육훈련을 받은 집단과 그렇지 않은 집단 간의 조직효과성(종속변수)의 차이는 없다고 할 수 있다.

결국, 서울특별시 소방학교 직무중심 집합교육훈련은 소방조직효과성에 긍정적인 영향을 미치지 못하고 있 으며, 이에 관한 과학적이고 체계적인 교육훈련 프로그 램의 재설계가 절실히 요구된다고 할 수 있다. 
4. $\mathrm{AHP}$ 를 이용한 직무중심 교육훈련 설계 : 재난관리 4단계(예방-대비-대응-복구)를 $\mathrm{AHP}$ 모형에 적용

\section{1 재난관리 단계별 하위기준 설정}

서울특별시소방학교 직무중심 교육훈련을 재설계하 는데 있어 재난관리 우선순위를 반영한다는 것은 '재난 관리조직이 재난현장에서 어떻게 재난문제를 효과적으 로 해결할 수 있는가'로 매우 중요한 의미를 갖는다[3]. 그리고 이는 재난관리를 소방교육훈련 프로그램에 접 목시킨다는 점에서 전국 소방학교가 지역특성 및 여건 에 맞는 교육훈련 프로그램을 설계하는데 매우 유용한 정보가 될 것이다.

이에 본 연구에서는 재난관리 4단계(예방-대비-대응 -복구) [4] 를 상위기준으로 하고 이를 작은 특성들로 세분화하여 서울특별시소방학교가 우선적 또는 중점적 으로 추구해야 하는 직무중심 교육훈련 프로그램을 설 계하기 위한 $\mathrm{AHP}$ (계층분석)을 위한 계층구조를 2단계 로 구분하여, 1 단계를 상위기준 그리고 2 단계를 하위기 준으로 명명하였다.

1 단계 평가기준으로는 재난관리 4단계인 예방, 대비, 대응, 복구로 하였다. 이는 학계나 재난관리 부서 뿐 만 아니라 재난 및 안전관리기본법 제3조에서도 볼 수 있듯이 일반적으로 통용되는 개념이다.
2단계 평가기준으로는 예방의 하위기준으로 재난계 획, 시설점검, 안전교육을, 대비의 하위기준으로 유관기 관 등 체제구축, 조직관리, 자원확보를, 대응의 하위기 준으로 화재 등 재난, 구조, 구급, 현장안전을, 복구의 하위기준으로 건강관리, 화재조사를 선정하였다.

본 연구에서는 도출된 12 개 하위기준은 상위기준인 재난관리 단계(예방-대비-대응-복구)별로 세분화하였 다(<Table $10>$ 참조).

\section{$4.2 \mathrm{AHP}$ 분석결과}

$\mathrm{AHP}$ 기법을 이용하여 상위기준인 예방, 대비, 대응, 복구와 이들을 구성하는 하위기준들의 상대적 중요도 를 측정하여 분석한 다음, 이를 종합하여 대안의 우선 순위를 결정하는 방법을 제시하고자 한다.

\subsection{1 설문조사 및 데이터 수집}

본 연구는 재난관리 중요도를 가장 잘 반영하는 서 울특별시소방학교의 직무중심 교육훈련을 선정하기 위 한 평가기준들의 상대적인 중요도를 알아보기 위함이 다. 설문은 평가기준의 쌍대비교를 위해 $\operatorname{Saaty}(1980)$ 의 9점 척도법으로 하여 [5], 계층구조를 기초로 같은 상 위 특성을 가진 요소간의 상호비교가 가능하도록 설문 지를 작성하였다. 작성된 설문지를 가지고 재난관리 전 문가를 대상으로 설문조사를 실시하였다.

$<$ Table 10> Fire education \& training in SFA

\begin{tabular}{|c|c|c|}
\hline 상위기준 & 하위기준 & 서울특별시소방학교 교육훈련 프로그램 \\
\hline \multirow{3}{*}{ 예 방 } & 재난계획 & $\begin{array}{c}\text { ·소방기획능력향상/소방전술작전도완성/기획행정능력향상/소방통계 } \\
\text { 실무/소방법령 }\end{array}$ \\
\hline & 시설점검 & $\begin{array}{c}\text { ·예방지도/소방시설(전기,기계)/소방안전검사와지도/예방행정전문가 } \\
\text { 양성/소방특별조사 }\end{array}$ \\
\hline & 안전교육 & ·소방안전교육사(보수)/인형극연기자양성/안전교육역량향상 \\
\hline \multirow{3}{*}{ 대 비 } & 체제 구축 & ·경찰재난대응/국제긴급구조대응/국제소방관 \\
\hline & 조직관리 & $\begin{array}{c}\text { ·지휘관리더십/초급간부리더십/119상황관제사양성/상황운영요원양성 } \\
\text { /의용소방대 }\end{array}$ \\
\hline & 자원확보 & $\begin{array}{c}\text { 운전요원양성(일반,특수차)/전문응급구조사(자격증)/위험예지훈련교 } \\
\text { 관양성/화재진화사(자격증)/ } 119 \text { 소방영어실무/1급,2급인명구조사(자 } \\
\text { 격증)*/1급,2급전문응급구조사(자격증)/응급구조사(1급)마스터(자격 } \\
\text { 증)/위험물(자격증) }\end{array}$ \\
\hline \multirow{4}{*}{ 대 응 } & 화재 등 재난 & $\begin{array}{c}\text { 특수화재대응/화재진압/자연재해대응기술/상황관리/문화재전문소방 } \\
\text { 대/위험물질사고대응/소방전술(중급,고급)/산불재난대응/현장지휘/초 } \\
\text { 고층및지하연계복합건축물재난대응·고층건축물 } \\
\text { 화재/지하철사고대응/지진재난대응 }\end{array}$ \\
\hline & 구조 & $\begin{array}{c}\text { ·고층건축물특공대/인명구조(대테러)/생활안전구조/인명구조(수난,항 } \\
\text { 공,화학,지하철,해난,산악) }\end{array}$ \\
\hline & 구급 & .이륜구급대운영/BLS프로바이더/BLS-instructor/전문응급구조사 \\
\hline & 현장안전관리 & ·현장안전점검관/안전관리담당관 \\
\hline \multirow{2}{*}{ 복 구 } & 건강관리 & ·CISD/건강관리/PTSD/재난피해심리상담 \\
\hline & 화재조사 & ·화재조사/화재조사 보수 \\
\hline
\end{tabular}


본 연구를 위한 $\mathrm{AHP}$ 설문조사는 2013년 7월 15일부 터 동년 동월 26 일까지 약 2 주에 걸쳐 실시하였다. 조 사대상은 현재 서울특별시 산하 소방서에서 근무하고 있는 25년 이상의 화재진압, 구조, 구급 등 재난현장 활동과 소방학교에서 전임교수로 활동했던 재난전문가 3 명, 소방안전관련 대학교수 3 명, 현재 서울특별시소방 학교 교육훈련기획 및 운영 관리자 2 명, 총 8 명을 선정 하여 조사를 실시하였다. 이 들 대상으로 일관성없는 설문조사 자료는 설문대상자에게 환류(feedback)를 받 아 개개인의 자료에 대한 일관성을 검증을 개별적으로 실시하고, 통합적으로 일관성 검증을 실시하였다.

\subsection{2 평가기준의 상대적 중요도 분석결과}

표본선정과 데이터 수집, 기초자료 평가의 과정을 거 쳐 $\operatorname{Saaty}(1980)$ 의 방법론에 의한 기하평균을 종합하여 작성된 행렬을 바탕으로 소방학교 직무중심 집합교육 훈련 프로그램에 있어서 재난관리의 상대적 중요도를 분석하였다.

\subsubsection{1 상위기준의 상대적 중요도 측정}

서울특별시소방학교 직무중심 집합교육훈련에 있어 서 최적의 교육프로그램을 설계하기 위하여 4 가지 항 목을 $\mathrm{AHP}$ 기법을 통하여 분석한 결과 상위기준의 상 대적 중요도는 대비가 0.345 로 가장 높게 나왔고, 대응 (0.314), 예방(0.233), 복구(0.108) 순으로 나타났다.

$<$ Table $11>$ AHP of high level

\begin{tabular}{|c||c|c|c|c||c|}
\hline 상위기준 & 예방 & 대비 & 대응 & 복구 & $\begin{array}{c}\text { 중요 } \\
\text { 도 }\end{array}$ \\
\hline \hline 예방 & 1 & 0.71284 & 0.62136 & 2.44949 & 0.233 \\
\hline 대비 & 1.40284 & 1 & 1.29885 & 2.87779 & 0.345 \\
\hline 대응 & 1.60937 & 0.76991 & 1 & 2.82246 & 0.314 \\
\hline 복구 & 0.40825 & 0.34749 & 0.35430 & 1 & 0.108 \\
\hline $\mathrm{CR}=0.075$ \\
\hline
\end{tabular}

상위기준에 대한 분석결과로서, 상위기준의 중요도 (가중치), 일관성 비율 $(\mathrm{CR})$ 을 나타내고 있는데, 일관성 비율 $(\mathrm{CR})$ 은 0.075 이고, 이는 0.1 이하이므로 일관성 있는 수치로 받아들여진다. 그리고 이에 앞서 설문대상 총 8 명(재난전문가 3 명, 소방교육훈련 기획 및 운영관리자 2 명, 학계 소방관련학과 교수 3 명)에 대한 각각의 일관 성 비율 $(\mathrm{CR})$ 은 모두 0.1 이하로 일관성 검증*을 실시하 였다 (<Table $11>$ 참조)

\subsubsection{2 하위기준의 상대적 중요도 측정}

$\mathrm{AHP}$ 분석결과 예방 항목에 포함되어 있는 하위기준 의 상대적 중요도는 재난계획이 0.274 , 시설점검이 0.350 , 안전교육이 0.376으로 나타났다. 대비 항목에 포 함되어 있는 하위기준의 중요도는 체제구축이 0.300 , 조직관리가 0.208 , 자원확보가 0.492 로 나타났다. 대응 항목에 포함되어 있는 하위기준의 중요도는 화재 등 재난이 0.360 , 구조가 0.219 , 구급이 0.240 , 현장안전이 0.182 로 나타났다. 마지막으로 복구 항목에 포함되어 있는 하위기준의 중요도는 화재조사가 0.639 , 건강관리 0.361 로 나타났다.

동일 상위기준 내에서의 하위기준에 대한 분석결과 로서, 일관성 비율 $(\mathrm{CR})$ 은 각각 $0.0002,0.0001,0.0058$, 0.0000 이고, 이는 0.1 이하이므로 일관성 있는 수치로 받아들여진다(<Table 12> 참조).

$<$ Table 12> AHP of low within high level

\begin{tabular}{|c||c|c|c||c|}
\hline 예방 & 재난계획 & 시설점검 & 안전교육 & 중요도 \\
\hline \hline 재난계획 & 1 & 0.79934 & 0.716448 & 0.274 \\
\hline 시설점검 & 1.25103 & 1 & 0.95058 & 0.350 \\
\hline 안전교육 & 1.39578 & 1.05199 & 1 & 0.376 \\
\hline $\mathrm{CR}=0.0002$ \\
\hline
\end{tabular}

\begin{tabular}{|c||c|c|c||c|}
\hline 대비 & 체제구축 & 조직관리 & 자원확보 & 중요도 \\
\hline \hline 체제구축 & 1 & 1.42728 & 0.61636 & 0.300 \\
\hline 조직관리 & 0.70063 & 1 & 0.41789 & 0.208 \\
\hline 자원확보 & 1.62243 & 2.39297 & 1 & 0.492 \\
\hline $\mathrm{CR}=0.0001$ & \multicolumn{5}{l|}{} \\
\hline
\end{tabular}

\begin{tabular}{|c||c|c|c|c||c|}
\hline 대응 & $\begin{array}{c}\text { 화재등 } \\
\text { 재난 }\end{array}$ & 구조 & 구급 & $\begin{array}{c}\text { 현장안 } \\
\text { 전 }\end{array}$ & $\begin{array}{c}\text { 중요 } \\
\text { 도 }\end{array}$ \\
\hline \hline $\begin{array}{c}\text { 화재등 } \\
\text { 재난 }\end{array}$ & 1 & 1.89742 & 1.28642 & 1.98393 & 0.360 \\
\hline 구조 & 0.52703 & 1 & 1.06759 & 1.18382 & 0.219 \\
\hline 구급 & 0.77735 & 0.93669 & 1 & 1.31607 & 0.240 \\
\hline 현장안전 & 0.50405 & 0.84472 & 0.75984 & 1 & 0.182 \\
\hline $\mathrm{CR}=0.0058$ & \multicolumn{5}{|l}{} \\
\hline
\end{tabular}

\begin{tabular}{|c||c|c||c|}
\hline 복구 & 화재조사 & 건강관리 & 중요도 \\
\hline \hline 화재조사 & 1 & 1.76923 & 0.639 \\
\hline 건강관리 & 0.56522 & 1 & 0.361 \\
\hline $\mathrm{CR}=0.0000$ & \multicolumn{3}{|l}{} \\
\hline
\end{tabular}

* 1 급, 2 급 인명구조사(자격증)은 대비단계와 대응단계 중복처리하였음(이는 1 급, 2 급 응급구조사와 달리 구조활동을 제약하거나 활동영역을 법 정으로 지정되지 않은 사항임을 감안할 때 중복적으로 처리함.)(03)

* 일부 설문대상자에 대한 일관성 지수가 0.1 보다 높은 경우는 환류(feedback)를 통해 보정 및 일관성을 유지(04). 


\subsubsection{3 전체 평가기준의 중요도 종합분석}

최적의 직무중심 교육훈련 프로그램을 작성하기 위 한 상위기준과 하위기준의 중요도 산출결과를 종합해 보면 하위기준 전체 내에서의 중요도는 상위기준의 중 요도와 동일 상위기준 내에서의 하위기준의 중요도를 곱으로 계산된다. 상위기준인 예방, 대비, 대응, 복구의 합은 1 이 되고, 각 상위기준에 포함되는 하위기준의 중 요도의 합도 1 이 된다. 또한 하나의 상위기준 항목내의 하위기준들의 동일수준 전체 내에서의 중요도의 합은 그 상위기준의 중요도와 같다. 가령, 상위기준인 예방 의 중요도 0.233 은 하위기준인 재난계획, 시설점검, 안 전교육의 동일수준 전체 내 중요도의 합 $(0.064+0.082$ $+0.087=0.233)$ 과 같다는 의미이다. 이는 계층적 의사결 정기법의 분해원리로 바로 위 상위단계의 중요도가 그 하위단계로 그대로 이전된 것이기 때문이다[6].

이는 재난전문가 3 명, 소방학교 교육기획 및 운영관 리자 2명, 소방관련 학계 교수 3 명 총 8 명에 대한 집단 의사결정을 $\mathrm{AHP}$ 기법에 적용하는 것에 관해서 Saaty 는 (1) 집단구성원 전원의 합의에 의한 평가를 구하는 방법과 (2) 집단구성원 개개인의 쌍대비교행렬의 값들 을 기하평균하여 집단안(案)을 구하는 방법을 제안하였 다 [7]. 본 연구에서는 (2)안을 채택하여 $\mathrm{AHP}$ 설문 대상자 8 명의 개개인들의 쌍대비교행렬의 값들을 기하 평균하여 값을 구하고 최종적으로 $\mathrm{AHP}$ 에 적용하여 중 요도(값)를 도출하였다(<Table $13>$ 참조).

$<$ Table $13>$ Final results of AHP

\begin{tabular}{|c|c|c|c|c|}
\hline 상위기준 & $\begin{array}{c}\text { 중요 } \\
\text { 도 }\end{array}$ & 하위기준 & $\begin{array}{c}\text { 동일 } \\
\text { 상위평가기준 } \\
\text { 내에서의 } \\
\text { 중요도 }\end{array}$ & $\begin{array}{c}\text { 하위기준 } \\
\text { 전체 } \\
\text { 내에서의 } \\
\text { 중요도 }\end{array}$ \\
\hline \multirow{3}{*}{ 예방 } & \multirow{3}{*}{0.233} & 재난계획 & 0.274 & $0.064(10)$ \\
\hline & & 시설점검 & 0.350 & $0.082(5)$ \\
\hline & & 안전교육 & 0.376 & $0.087(4)$ \\
\hline \multirow{3}{*}{ 대비 } & \multirow{3}{*}{0.345} & 체제구축 & 0.300 & $0.104(3)$ \\
\hline & & 조직관리 & 0.208 & $0.072(7)$ \\
\hline & & 자원확보 & 0.492 & $0.170(1)$ \\
\hline \multirow{4}{*}{ 대응 } & \multirow{4}{*}{0.314} & $\begin{array}{c}\text { 화재등재 } \\
\text { 난 }\end{array}$ & 0.360 & $0.113(2)$ \\
\hline & & 구조 & 0.219 & $0.069(9)$ \\
\hline & & 구급 & 0.240 & $0.075(6)$ \\
\hline & & 현장안전 & 0.182 & $0.057(11)$ \\
\hline \multirow{2}{*}{ 복구 } & \multirow{2}{*}{0.109} & 건강관리 & 0.361 & $0.039(12)$ \\
\hline & & 화재조사 & 0.639 & $0.070(8)$ \\
\hline
\end{tabular}

※( )안의 숫자는 교육훈련에서 재난관리 중요도의 우선순위를 말함.
각 단계의 중요도를 종합하여 분석해 본 결과, 하위 기준 전체 내에서의 중요도는 대비 항목의 하위기준인 자원확보가 0.170 으로 가장 높게 나타났으며, 그 다음 화재 등 재난(0.113), 체제구축(0.104), 안전교육(0.087), 시설점검(0.082), 구급(0.075), 조직관리(0.072), 화재조사 (0.070), 구조(0.069), 재난계획(0.064), 현장안전(0.057), 건강관리(0.039) 순으로 나타났다. 이를 통해 서울특별시 소방학교 직무중심 교육훈련이 어떠한 교육훈련을 중점 적으로 기획·운영해야 하는지 알 수 있다. 즉, 서울특별 시소방학교 직무중심 교육훈련은 대비단계와 관련된 교 육훈련을 가장 중점적으로 추진하고, 그 중에서도 자원 확보와 관련된 교육훈련을 중점적으로 이루어져야 한다.

\section{3 교육훈련 프로그램 설계 방향}

4.3.1 2013년도 현재 서울특별시소방학교 직무 중심 교육훈련의 중요도(비중)

서울특별시소방학교에서 운영(2013)하고 있는 '직무 중심 교육훈련 시간과 교육훈련인원(교육훈련시간 $\mathrm{x}$ 교육훈련인원)은 그 집합교육훈련의 비중이다.' 라는 것 을 전제로 한다. 그 외 교육장, 교수인원, 교육 기자재 등 외부 변수들이 작용하기는 하나 이는 오랜 시간동 안 형성되어 온 요인이기 때문에 통제하기로 한다.

\subsubsection{1 서울소방학교 교육훈련의 현황}

2013년 서울특별시 소방학교 직무중심 교육훈련 시간과 교육인원을 재난관리 단계별로 나타낸 것이다. 여기서 재 난관리와 관련이 적었던 '경력개발 및 설계*'와 '교수요 원양성' 반은 제외시켰고, 소방공무원과 의용소방대원을 대상으로 하는 직무 집합교육훈련만을 대상으로 하였다.

4.3.1.2 재난관리 단계별 직무중심 교육훈련 비중 상위기준인 재난관리 단계별 예방-대비-대응-복구의 우선순위는 대비(47.0\%), 대응(21.2\%), 예방(19.8\%), 복 구(12.0\%) 순이었고, 하위기준의 우선순위는 자원확보 (29.8\%), 조직정비(16.4\%), 시설점검(10.1\%), 화재 등 재난(11.5\%), 화재조사(8.7\%), 구급(6.1\%), 재난계획 (5.9\%), 안전교육(3.8\%), 건강관리(3.3\%), 구조(2.1\%), 현장안전(1.5\%), 체제구축(0.7\%)순이었다.

서울특별시소방학교의 직무중심 집합교육훈련은 재난 관리 단계별(상위기준)로 보았을 때 대비를 가장 중점 적으로 교육훈련하고 있으며 예방관련 교육훈련을 중점 적으로 하고 있음을 알 수 있었다. 그리고 복구는 매우 한정적으로만 교육훈련하고 있었다(Table 14 참조).

* '경력개발 및 설계'는 35시간 x 4회, 총 92명을 대상으로 교육, '교수요원양성'은 21시간 x 1회, 총 23명 대상으로 교육실시(05). 
$<$ Table14 $>$ Percentage rank of fire education \& training in SFA(2013)*

\begin{tabular}{|c|c|c|c|c|c|c|c|}
\hline \multicolumn{2}{|c|}{ 계층구조 } & \multirow[b]{2}{*}{$\begin{array}{c}\text { 직무중심 } \\
\text { 집합교육훈련 }\end{array}$} & \multirow[b]{2}{*}{$\begin{array}{c}\text { 교육훈련 } \\
\text { 시 간 }\end{array}$} & \multirow[b]{2}{*}{$\begin{array}{l}\text { 기당 } \\
\text { 인원 }\end{array}$} & \multicolumn{3}{|c|}{ 비 중 } \\
\hline $\begin{array}{l}\text { 상위 } \\
\text { 기준 }\end{array}$ & $\begin{array}{l}\text { 하위 } \\
\text { 기준 }\end{array}$ & & & & 시간x인원 & 백분율 & 순위** \\
\hline \multicolumn{3}{|c|}{ 총 계 } & 3,415시간 & 1,552 & 125,118 & $100 \%$ & 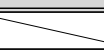 \\
\hline \multirow{10}{*}{ 예 } & \multicolumn{2}{|c|}{ 소 계(합) } & 707시간 & 318명 & 24,766 & $19.8 \%$ & 3 \\
\hline & \multirow{4}{*}{ 재난계획 } & 기획행정능력향상 & 35시간 $\mathrm{x}$ 4회 & 23명 & 3,220 & \multirow{4}{*}{$5.9 \%$} & \multirow{4}{*}{ (7) } \\
\hline & & 소방법령 & 35시간 x 1회 & 44명 & 1,540 & & \\
\hline & & 소방통계실무 & 35시간 $\times 2$ 회 & 23명 & 1,610 & & \\
\hline & & 소방전술작전도완성 & 21시간 $\times 2$ 회 & 23명 & 966 & & \\
\hline & \multirow{3}{*}{ 시설점검 } & $\begin{array}{l}\text { 소방안전검사와 } \\
\text { 지도 }\end{array}$ & 70시간 $\times 2$ 회 & 44명 & 6,160 & \multirow{3}{*}{$10.1 \%$} & \multirow{3}{*}{ (3) } \\
\hline & & 소방시설(기계) & 35시간 x 2회 & 46명 & 3,220 & & \\
\hline & & 소방시설(전기) & 35시간 x 2회 & 46명 & 3,220 & & \\
\hline & \multirow{2}{*}{ 안전교육 } & 안전교육역량향상 & 35시간 $\times$ 2회 & 23명 & 1,610 & \multirow{2}{*}{$3.8 \%$} & \multirow{2}{*}{ (8) } \\
\hline & & 소방안전교육사 & 35시간 $\times$ 2회 & 46명 & 3,220 & & \\
\hline \multirow{13}{*}{ 비 } & \multicolumn{2}{|c|}{ 소 계(합) } & 1,603 시간 & 384명 & 58,822 & $47.0 \%$ & 1 \\
\hline & \multirow[t]{2}{*}{ 체제구축 } & $\begin{array}{c}\text { International } \\
\text { Course }\end{array}$ & 35 시간 x 1회 & 5 명 & 175 & \multirow[t]{2}{*}{$0.7 \%$} & \multirow[t]{2}{*}{ (12) } \\
\hline & & 국제소방관교육제도 & 28시간 x 1회 & 25명 & 700 & & \\
\hline & & 지휘관리더십 & 70시간 $\times 6$ 회 & 44명 & 18,480 & & \\
\hline & 조직정비 & 119상황관제사 양성 & 35시간 x 1회 & 30명 & 1,050 & $16.4 \%$ & (2) \\
\hline & & 의용소방대 & 7시간 x 3회 & 50명 & 1,050 & & \\
\hline & & 운전요원양성(일반) & 70시간 $\mathrm{x}$ 4회 & 23명 & 6,440 & & \\
\hline & & $\begin{array}{c}\text { 운전요원양성 } \\
\text { (특수차) }\end{array}$ & 35시간 x 2회 & 23명 & 1,610 & & \\
\hline & 자원확보 & $\begin{array}{c}\text { 위험예지훈련교관양 } \\
\text { 성 }\end{array}$ & 7시간 x 2회 & 23명 & 322 & $29.8 \%$ & (1) \\
\hline & & 위험물 & 35시간 $\times$ 2회 & 46명 & 3,220 & & \\
\hline & & 응급구조사(1급) & 140시간x1회 & 40명 & 5,600 & & \\
\hline & & 응급구조사(2급) & 315시간x1회 & 50명 & 15,750 & & \\
\hline & & 인명구조사-(2급) & 175시간x1회 & 25명 & 4,375 & & \\
\hline & & (햅) & 586시간 & 681명 & 26,500 & $21.2 \%$ & 2 \\
\hline & & 소방전술(중급) & 70시간 $\times$ 2회 & 44명 & 6,160 & & \\
\hline & & 소방전술(고급) & 35시간 x 1회 & 44명 & 1,540 & & \\
\hline & 화재 등 재난 & 위험물질사고대응 & 35시간 $\times 2$ 회 & 44명 & 3,080 & $11.5 \%$ & (4) \\
\hline 대 & & 자연재해대응기술 & 21시간 x 4회 & 23명 & 1,932 & & \\
\hline & & 고층건축물화재대응 & 14시간 x 3회 & 40명 & 1,680 & & \\
\hline 응 & 구조 & 생활안전구조 & 14시간 x 4회 & 46명 & 2,576 & $2.1 \%$ & (10) \\
\hline & & 전문응급구조사 & 35시간 x 1회 & 24명 & 840 & & \\
\hline & 구급 & 응급구조사 마스터 & 35시간 x 2회 & 40명 & 2,800 & $6.1 \%$ & (6) \\
\hline & & 응급구조사 보수 & 4시간 x 3회 & 330명 & 3,960 & & \\
\hline & 현장안전 & 현장안전점검관 & 21시간 x 2회 & 46 명 & 1,932 & $1.5 \%$ & (11) \\
\hline & 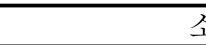 & 해합) & 519시간 & 169명 & 15,030 & $12.0 \%$ & 4 \\
\hline & 거가과기 & CISD & 70시간 x 1회 & 44명 & 3,080 & 320 & (9) \\
\hline 복 구 & 건강관리 & 재해피해 심리상담 & 7시간 x 3회 & 50명 & 1,050 & $3.3 \%$ & (9) \\
\hline & & 화재조사 & 420시간x1회 & 25명 & 10,500 & $87 \%$ & (5) \\
\hline & 화재조사 & 화재조사 보수 & 4시간 x 2회 & 50명 & 400 & $8.1 \%$ & (5) \\
\hline
\end{tabular}

※ 1 4)은 상위기준의 우선순위이고, (1) (10)은 하위기준의 우선순위임.

* 서울소방학교 교육훈련 대상은 소방공무원 및 의용소방대 등 소방인력만을 포함하고 일반시민이나 유관기관 종사자에 대한 교육훈련은 포함하 지 않음(06). 
4.3.2 $\mathrm{AHP}$ 분석결과에 의한 직무중심 교육훈련 프로그램의 설계

\subsubsection{1 예방단계의 직무중심 교육훈련}

$<$ Table 15> Fire education \& training of Prevention

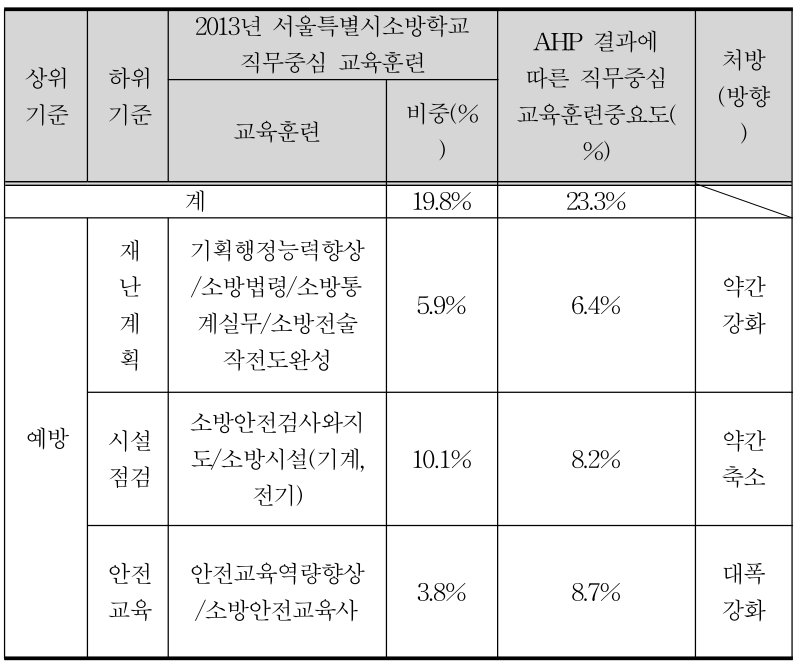

$\mathrm{AHP}$ 분석결과와 서울소방학교 교육훈련을 비교한 결과 서울특별시소방학교 교육훈련 중 「예방」과 관련 된 교육훈련은 전체적으로 강화하여야 한다. 구체적으 로 '재난계획'과 관련된 교육훈련은 약간강화 $(+0.5 \%)$, '시설점검'과 관련된 교육훈련은 약간축소 $(-1.9 \%)$, '안 전교육'과 관련 교육훈련은 대폭 강화 $(+4.9 \%)$ 하여야 한 다(<Table 15> 참조).

\subsubsection{2 대비단계의 직무중심 교육훈련}

$<$ Table 16> Fire education \& training of Preparedness

\begin{tabular}{|c|c|c|c|c|c|}
\hline \multirow{2}{*}{$\begin{array}{l}\text { 상위 } \\
\text { 기준 }\end{array}$} & \multirow{2}{*}{$\begin{array}{l}\text { 하위 } \\
\text { 기준 }\end{array}$} & \multicolumn{2}{|c|}{$\begin{array}{c}\text { 2013년 서울특별시소방학교 } \\
\text { 직무중심 교육훈련 }\end{array}$} & \multirow{2}{*}{$\begin{array}{c}\text { AHP결과에 } \\
\text { 따른 직무중심 } \\
\text { 교육훈련중요도( } \\
\%)\end{array}$} & \multirow{2}{*}{$\begin{array}{l}\text { 처방 } \\
\text { (방향) }\end{array}$} \\
\hline & & 교육훈련 & 비중(\%) & & \\
\hline \multicolumn{3}{|r|}{ 계 } & 47.0\% & $34.5 \%$ & 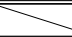 \\
\hline \multirow[b]{3}{*}{ 대비 } & $\begin{array}{l}\text { 체제 } \\
\text { 구축 }\end{array}$ & $\begin{array}{c}\text { International } \\
\text { Course/국제소방 } \\
\text { 관교육제도 }\end{array}$ & $0.7 \%$ & $10.4 \%$ & $\begin{array}{l}\text { 대 폭 } \\
\text { 강 화 }\end{array}$ \\
\hline & $\begin{array}{l}\text { 조직 } \\
\text { 정비 }\end{array}$ & $\begin{array}{c}\text { 지휘관리더십/119 } \\
\text { 상황관제사/의용- } \\
\text { 소방대 }\end{array}$ & $16.4 \%$ & $7.2 \%$ & $\begin{array}{l}\text { 대 폭 } \\
\text { 축 소 }\end{array}$ \\
\hline & $\begin{array}{l}\text { 자원 } \\
\text { 확보 }\end{array}$ & $\begin{array}{c}\text { 운전요원양성(일 } \\
\text { 반)/운전요원양성 } \\
\text { (특수차)/위험예 } \\
\text { 지훈련교관양성/ } \\
\text { 위험물(자격증)/ } \\
\text { 응급구조사(1급)/ } \\
\text { 응급구조사(2급)/ } \\
\text { 인명구조사(2급) }\end{array}$ & $29.8 \%$ & $17.0 \%$ & $\begin{array}{l}\text { 대 폭 } \\
\text { 축 소 }\end{array}$ \\
\hline
\end{tabular}

$\mathrm{AHP}$ 분석결과와 서울소방학교 교육훈련을 비교한 결과 서울특별시소방학교 교육훈련 중 「대비」와 관련 된 교육훈련은 전체적으로 축소하여야 한다. 구체적으 로 '체제구축'과 관련된 교육훈련은 대폭강화 $(+9.7 \%)$, '조직정비'와 관련된 교육훈련은 대폭축소 $(-9.2 \%)$, '자 원확보'와 관련 교육훈련은 대폭 축소(-12.8\%)하여야 한다. 따라서 대비단계의 교육훈련은 다른 재난관리 단 계보다 많이 '자원확보' 및 '조직정비'와 관련된 교육훈 련 프로그램을 줄이고, '체제구축'과 관련된 유관기관과 국제협조와 관련된 교육훈련 프로그램을 획기적으로 늘려 편성하여 강화할 필요가 있다(<Table 16> 참조).

\subsubsection{3 대비단계의 직무중심 교육훈련}

$<$ Table 17> Fire education \& training of Response

\begin{tabular}{|c|c|c|c|c|c|}
\hline \multirow{2}{*}{$\begin{array}{l}\text { 상 } \\
\text { 위 } \\
\text { 기 } \\
\text { 준 }\end{array}$} & \multirow{2}{*}{$\begin{array}{l}\text { 하위 } \\
\text { 기준 }\end{array}$} & \multicolumn{2}{|c|}{$\begin{array}{c}\text { 2013년 } \\
\text { 서울특별시소방학교 } \\
\text { 직무중심 교육훈련 }\end{array}$} & \multirow{2}{*}{$\begin{array}{c}\mathrm{AHP} \text { 결과에 } \\
\text { 따른 } \\
\text { 직무중심 } \\
\text { 교육훈련중요 } \\
\text { 도(\%) }\end{array}$} & \multirow{2}{*}{$\begin{array}{l}\text { 처방 } \\
\text { (방향) }\end{array}$} \\
\hline & & 교육훈련 & $\begin{array}{c}\text { 비중( } \\
\%)\end{array}$ & & \\
\hline \multicolumn{3}{|c|}{ 계 } & $21.2 \%$ & $31.4 \%$ & \\
\hline \multirow{4}{*}{$\begin{array}{l}\text { 대 } \\
\text { 응 }\end{array}$} & $\begin{array}{l}\text { 화재 } \\
\text { 등 } \\
\text { 재난 }\end{array}$ & $\begin{array}{c}\text { 소방전술(중 } \\
\text { 급,고급)/위험 } \\
\text { 물질사고대응 } \\
\text { /자연재해대 } \\
\text { 응기술/고층 } \\
\text { 건축물화재대 } \\
\text { 응 }\end{array}$ & $11.5 \%$ & $11.3 \%$ & $\begin{array}{l}\text { 현 } \\
\text { 수준 } \\
\text { 유지 }\end{array}$ \\
\hline & $\begin{array}{l}\text { 구 } \\
\text { 조 }\end{array}$ & 생활안전구조 & $2.1 \%$ & $6.9 \%$ & $\begin{array}{l}\text { 대 폭 } \\
\text { 강 화 }\end{array}$ \\
\hline & $\begin{array}{l}\text { 구 } \\
\text { 급 }\end{array}$ & $\begin{array}{c}\text { 전문응급구조 } \\
\text { 사/응급구조 } \\
\text { 사마스터/응 } \\
\text { 급구조사 } \\
\text { 보수 }\end{array}$ & $6.1 \%$ & $7.5 \%$ & $\begin{array}{l}\text { 약 간 } \\
\text { 강 화 }\end{array}$ \\
\hline & $\begin{array}{l}\text { 현장 } \\
\text { 안전 }\end{array}$ & $\begin{array}{c}\text { 현장안전점검 } \\
\text { 관 }\end{array}$ & $1.5 \%$ & $5.7 \%$ & $\begin{array}{l}\text { 대 폭 } \\
\text { 강 화 }\end{array}$ \\
\hline
\end{tabular}

$\mathrm{AHP}$ 분석결과와 서울소방학교 교육훈련을 비교한 결과 서울특별시소방학교 교육훈련 중 「대응」과 관 련된 교육훈련은 전체적으로 강화하여야 한다. 구체적 으로 '화재 등 재난'과 관련된 교육훈련은 현재 수준유 지 $(-0.2 \%)$, '구조'와 관련된 교육훈련은 약간강화 $(+1.4 \%)$, '현장안전'과 관련 교육훈련은 대폭 강화 $(+4.2 \%)$ 하여야 한다(<Table $17>$ 참조). 
4.3.2.4 복구단계의 직무중심 교육훈련

$<$ Table 18> Fire education \& training of Recovery

\begin{tabular}{|c|c|c|c|c|c|}
\hline \multirow{4}{*}{$\begin{array}{l}\text { 상위 } \\
\text { 기준 }\end{array}$} & \multirow{4}{*}{$\begin{array}{l}\text { 하 } \\
\text { 위 } \\
\text { 기 } \\
\text { 준 }\end{array}$} & \multirow{3}{*}{\multicolumn{2}{|c|}{$\begin{array}{c}\text { 2013년 } \\
\text { 서울특별시소방학교 } \\
\text { 직무중심 교육훈련 }\end{array}$}} & \multirow{4}{*}{$\begin{array}{c}\mathrm{AHP} \text { 결과에 } \\
\text { 따른 직무중심 } \\
\text { 교육훈련 } \\
\text { 중요도(\%) } \\
\end{array}$} & \multirow{4}{*}{$\begin{array}{l}\text { 처방 } \\
\text { (방향) }\end{array}$} \\
\hline & & & & & \\
\hline & & & & & \\
\hline & & 교육훈련 & 비중(\%) & & \\
\hline \multicolumn{3}{|c|}{ 계 } & $12.0 \%$ & $10.9 \%$ & \\
\hline \multirow{2}{*}{ 복구 } & $\begin{array}{l}\text { 건 } \\
\text { 강 } \\
\text { 관 } \\
\text { 리 }\end{array}$ & $\begin{array}{c}\mathrm{CISD} / \text { 재해 } \\
\text { 피해 } \\
\text { 심리상담 }\end{array}$ & $3.3 \%$ & $3.9 \%$ & $\begin{array}{l}\text { 약 간 } \\
\text { 강 화 }\end{array}$ \\
\hline & $\begin{array}{l}\text { 화 } \\
\text { 재 } \\
\text { 조 } \\
\text { 사 }\end{array}$ & $\begin{array}{l}\text { 화재조사/화 } \\
\text { 재조사 보수 }\end{array}$ & $8.7 \%$ & $7.0 \%$ & $\begin{array}{l}\text { 약 간 } \\
\text { 축 소 }\end{array}$ \\
\hline
\end{tabular}

$\mathrm{AHP}$ 분석결과와 서울소방학교 교육훈련을 비교한 결과 서울특별시소방학교 교육훈련 중「복구」와 관 련된 교육훈련은 전체적으로 약간 축소하여야 한다. 구 체적으로 '건강관리'와 관련된 교육훈련은 약간 강화 $(+0.6 \%)$, '화재조사'와 관련된 교육훈련은 약간축소 $(-1.72 \%)$ 하여야 한다(Table 18 참조). 그러나 서울특별 시소방학교에서 화재조사관련 교육훈련을 하기 위해서 는 전국 소방학교의 화재조사 교육훈련과 마찬가지로 소방기본법시행규칙 제 12 조(화재전담부서의 설치·운영 등) 제 3 항 제 1 호에 의하며 '소방교육기관에서 12 주 이 상 화재조사에 관한 전문교육을 이수한 자'로 규정되어 있어서 교육훈련 비중은 고정화되어 있다. 결국 이러한 법령사항은 준수하되 소방공무원의 외상후 스트레스 장애 등 건강관리 교육훈련 프로그램을 강화시키는 방 향으로 교육훈련이 강화되어야한다(<Table 18> 참조).

\section{5. 결 론}

\section{1 연구의 결과 및 한계}

\subsection{1 연구의 결과}

실증분석(회귀분석 및 $\mathrm{T}$-검정) 결과, 서울특별시소방 학교 직무중심 교육훈련이 조직 효과성에 유의미하게 긍정적인 영향을 주지 못하고 있음이 검증되었다. 이에 대한 대책으로 소방조직의 효과성을 제고시킬 수 있는 수요자 중심의 교육훈련 프로그램 설계를 $\mathrm{AHP}$ 를 통해 현재 교육훈련 프로그램 현황을 파악하고, 재난관리 중 요도를 산정하여 과학적이고 체계적인 직무중심 교육 훈련 프로그램 내용과 방향을 제시할 수 있었다.

구체적으로 서울특별시소방학교 직무중심 교육훈련은 첫째「예방」과 관련된 교육훈련은 강화하여야 한다. 둘째「대비」와 관련된 교육훈련은 축소하여야 한다.
셋째「대응」과 관련된 교육훈련은 강화하여야 한다. 넷째「복구」와 관련된 교육훈련은 약간 축소하여야 한다. 다만 세부 교육훈련 내용은 앞서 제시한 Table 15 18에서 보는 바와 같이 강-약 조절이 이루어져야 할 것이다.

\section{1 .2 연구의 한계}

본 연구는 다음과 같은 한계가 존재한다. 소방학교 교육훈련이 조직효과성이 얼마나 영향을 주는지와 관 련하여 소방조직 특성상 교육훈련이 얼마큼의 비중으 로 조직효과성에 영향을 줄 수 있는지와 교육훈련 전 이가 소방조직에서는 어떻게 이루어지는지에 대한 보 다 치밀한 연구가 더 필요하다. 그리고 $\mathrm{AHP}$ 기법을 이용할 때 재난관리 4단계(예방-대비-대응-복구)를 상 위기준으로 하고 12 개 하위기준 개념에 관하여는 보다 치밀하게 설계가 요구되고, 기존 교육훈련 프로그램에 대한 진단에서 그칠 것이 아니라 새로운 개념의 교육 훈련 과정과 세부적인 교육훈련 교과목을 발굴 가능한 심도있는 연구가 필요하다. 이는 본 연구에서 사용된 $\mathrm{AHP}$ 기법을 교육훈련전문가, 재난전문가, 소방공무원 등을 통해 새로운 교육훈련 프로그램을 결정하고 반 영할 수 있도록 하는 추후 연구가 이루어져야 할 것이 다. 가령, 재난관련 교육훈련 프로그램을 설계하는데 있어 인위재난, 자연재난, 사회적 재난, 복합재난 등으 로 구분하고 그 하위기준을 계층화하여 결과를 얻을 수 있을 것이다.

\section{2 소방행정에의 시사점}

본 연구는 상기 제시된 검증상의 한계가 남아있지만, 서울특별시소방학교 개교 이래 진행되어 온 교육훈련 프로그램 실증분석과 재난관리 4단계를 $\mathrm{AHP}$ (계층분석) 에 적용하여 최초로 과학적이고 체계적인 교육훈련 프 로그램 설계를 제시하였다고 할 수 있다. 이는 구체적 인 교육훈련 프로그램의 내용에도 적용할 수 있어서 어떤 내용의 교육훈련 프로그램이 되어야 하는가에 대 한 실마리를 제공해 줄 수 있다. 이러한 교육훈련 프로 그램을 과학적이고 체계적인 방법으로 설계되고 적용 할 때 소방조직의 효과성에 기여하는 바가 매우 클 것 으로 예상된다. 이러한 방법에 의한 교육훈련 프로그램 은 소방학교를 포함한 모든 공공교육기관에게도 적용 시킬 수 있어 과거 답습적인 교육훈련 프로그램의 재 활용에서 벗어나 새로운 환경변화에 적극적으로 대응 하고 변화를 촉진할 수 있다는 측면에서 본 연구의 의 의가 크다고 할 수 있다. 


\section{References}

[1] J. Jin, A Review of Conceptualization and $\mathrm{Re}^{-}$co nceptualization of Organization Effectiveness, Kor ea Public Administration Review, 7(2), p.p83104(2003)

[2] VictorA. Thompson, Modern Organization(New York; Knopf), p.27(1964).

[3] David McLouglin, A Framework for Integrated Emergency Management, Public Administration Review 45, p.166(1985)

[4] Petak, Emergency Management: A Challenge for Public Administration. Public Administration Revi ew p45, p.3(1985)

[5] D. H. Yu, Analysis on Important Factors for Pre senting the Direction of Taekwondo Demonstrati on Team through Delphi/AHP, KYUNG HEE University, p.55(2009)

[6] I. G. Whang, A Study on the Selection of Dome stic Third-party Logistics Service Provider by using the AHP, SUNGKYUNKWAN Uinv., p.56 (2005)

[7] Kinosita Aijo, Ohoya Takao, Strategic Making de cision by $\mathrm{AHP}$ (Analytic Hierarchy Process), pp. 3-9(2012)
저 자 소 개

김 진 근

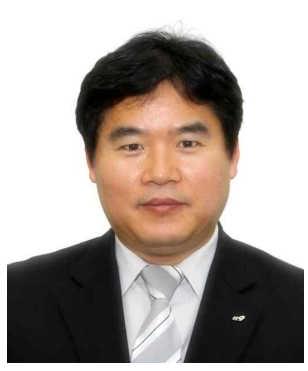

중앙대학교 경영학과 학사. 서울대학교 위기관리 석사. 서울시립대학교 재난과학과 박사과정. 소방간부 후보생 14 기. 현재 서울특별시 소방학교 소방과학연구센터 선임 연구원 으로 재직 중이며 관심분야는 재 난관리 · 소방교육훈련의 과학화 · 고층건물 소방안전 분야이며, 현재 서울종합방재센터 상 황요원 감정노동에 관한 연구를 진행 중이며, 소방학교 비전임 교수로 재난관리를 강의중이다.

주소 : 서울 서초구 신반포로 270 (반포동, 반포자이) $142-$ 2202

박 찬 석

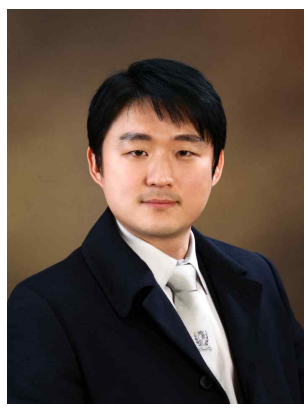

동국대학교 경찰행정학과 학사. 서울대학교 위기관리 석사. 서울시립대학교 재난과학과 박사. 소방간부 후보생 14 기. 현재 우송정보대학 소방안전 관리과 교수로 재직 중이며 관심분야는 재난관리 · 의용소방대 및 재난피해심리분야이며, 현장활 동 소방공무원 고령화 현상·화재피난시뮬레이션·소방 서 성과평가기준에 대한 연구를 진행중이며, 소방학개론. 소방법규·재난관리를 강의중이다.

주소 : 대전광역시 동구 자양동 226-2 우송정보대학 공학관 402호 